\title{
Organizational optimization through the double diamond - Applying Interdisciplinarity
}

Adriano Amaral Caulliraux', Delton Pedroso Bastos², Robson Araujo ${ }^{1}$, Stella Reis Costa ${ }^{1}$

${ }^{1}$ Federal Fluminense University, Laboratory of Technology, Business and Environment Management, Niteroi, RJ, Brazil. ${ }^{2}$ BastosJuris, Três Rios, RJ, Brazil

How to cite: Caulliraux, A.A., Bastos, D.P. Araujo, R. et al. (2020), “Organizational optimization through the double diamond - Applying Interdisciplinarity", Brazilian Journal of Operations \& Production Management, Vol. 17, No. 4, e2020917. https://doi.org/10.14488/BJOPM.2020.025

\section{ABSTRACT}

Goal: This article reports a project carried out by the company Respondit that had as its main objective the optimization of the organizational processes of the law firm BastosJuris. As a research question, we highlight: "Will the communion between Design Thinking, Lean Thinking and Process Management generate good project results?".

Design / Methodology / Approach: The methodology used was composed by Design Thinking, Process Engineering and Lean. The engagement with employees through prototyping and co-creation, focusing on productivity improvement and error elimination, seeking process optimization and implementation of a management model through continuous improvement, illustrates only one of the possible trajectories arising from mixed methodologies. In this case, "orchestrated" by the double diamond.

Results: The project described had an ROI of $815 \%$ during its execution and fostered several new initiatives for those involved.

Limitations of the investigation: As there is no similar research in the literature to compare with, it is not possible to induce success based in other initiatives.

Practical implications: The research shows practical results of the effectiveness of the methodology used in the interdisciplinary context. We seek to promote and encourage the development of similar new researches that take interdisciplinarity as a guide for organizational success.

Originality / Value: With regard to the academic contributions, the present study carried out the empirically and holistically variables linked to sustainable management practices, innovation, strategy and their consequent elements, in convergence with the research agenda of the management field, which focuses on results for individuals (employees) and organizations.

Keyword: Design Thinking; Innovation; Process Management; Lean Thinking; Interdisciplinarity.

\section{INTRODUCTION}

The field of Design, previously recognized only for its ability to deal with aesthetic and functional issues, began to spread its thinking about projects throughout other areas of the organization, rising to strategic levels related to its administration (Franzato, 2010). The term "strategic design" has come to be used to represent this change of interpretation with respect to the boundaries of Design's performance (Zurlo, 2004). The scope of strategic design encompasses product design, service, communication and experience in an integrated manner, in the so-called system-product (Cautela and Zurlo, 2006).

Financial support: None.

Conflict of interest: The authors have no conflict of interest to declare.

Corresponding author: adriano.a.caulliraux@gmail.com

Received: 09 Jan 2020

Accepted: 16 Jan 2020

Editor: Osvaldo L. G. Quelhas 
Design Thinking seeks solutions to complex problems by redefining the way in which they are interpreted and, consequently, how they are solved (Caulliraux et al., 2013). Martin (2009) presents - based on the thinking of scientist Charles Sanders Peirce - that Design thinking follows a third form of thinking, besides deduction and induction, the abductive thinking. As Peirce points out, "We should never commit ourselves to the truth of current scientific opinion, but instead we should accept it merely as a stage on the path to truth" (Garvey and Stangroom, 2009).

Peirce (1998) indicates that the scientific method is always submissive to the real - the tangible - and that through learning, correction, synthesis, enlargement and improvement we grow and evolve. Experience then has a corrective factor that feeds the intellect. Error induces correction, creating a new habit more suited to the continuity of existence (Muraro, 2008). An experiment is a mean to an end, not the end itself. It is an opportunity to create a situation in which people can collaborate and try things together, seeking tangibility and improvement of concepts. (Dickson et al., 2011).

Lean Manufacturing was created by Toyota at the end of World War II with the implementation of the Toyota Production System (TPS) (Monden, 1998). The aim of the TPS system was to increase productivity in car production and reduce costs by eliminating all types of MUDAs (waste).

In its most basic form, lean manufacturing is the systematic elimination of all activities of an organization that do not add value to the product, service and the process itself, increasing the value of each activity performed and eliminating what is not needed. To maximize its potential, it must be implemented in the supply chain or value stream, bringing benefits such as improved productivity, higher value added to products, reduced waste and greater customer satisfaction (Liker, 2005; Liao, 2005).

The article reports a project carried out by the company Respondit that had as its main objective the optimization of the organizational processes of the law firm BastosJuris. As a research question, we highlight: "Will the communion between Design Thinking, Lean Thinking and Process Management generate good project results?". The objective of this research is configured as the demonstration of effectiveness of the application of multiple methodologies from the perspective of Design Thinking.

The objective of this paper is to present the description of the application of the design thinking methodology, containing lean manufacturing inferences, in a process planning and management project that seeks the optimization and reduction of errors. The methodology used was the double diamond, which in addition to the co-creation and prototyping typical of the area, had as information sources the systematic review of the literature, quantitative research conducted with customers, among others.

Among the results of the project that will be described in this article, we highlight the $815 \%$ ROI during the execution, the improvement in the customer relationship logic and organizational marketing.

The international literature does not describe applied cases of design thinking integrated with lean thinking and process management. Thus, the contribution of this article is based on its interdisciplinary role, and its limitation is the lack of similar research in order to build a specific field of study.

Below is a brief review of the literature considering Design Thinking, Abductive Logic, Double Diamond and Process Management.

\section{LITERATURE REVIEW}

\section{Design Thinking}

Design Thinking seeks solutions to complex problems by redefining the way they are interpreted and, consequently, how they are solved (Caulliraux et al., 2013). It is recurrent in the literature the attempt to categorize basic premises of the area, among which stand out: holistic view - the whole system must be considered; user-centric - focused on actual user 
needs; co-creative - key contributors should be involved in the creative process; visual thinking - expressive ability developed through a designer's years of training; prototyping - concepts must be tested and refined in partnership with end users (Caulliraux, 2014).

Design Thinking incorporates to businesses the view that their existence is justified by the fact that they meet human needs, beliefs and values. Efficiency and standardization will always be part of business processes, however, it is the human aspects that influence the real user experience, providing products, services and brands with real value and meaning (Mootee, 2013).

One of the methodologies used in Design Thinking is the so-called "double diamond" first conceived by the Design Council in 2005 - which is composed of four stages, namely: Discovery; Definition; Development; Implementation. These stages represent the cycles of divergence and convergence intrinsic to Design thinking (Caulliraux et al., 2013).

\section{Abductive logic}

Charles Sanders Peirce (1839-1914) was an American scientist born in the city of Cambridge - Massachusetts, who devoted himself to research in various fields of knowledge, such as philosophy, mathematics, astrology, metrology, cartography, psychology, among others. He has 12,000 published pages, and at least another 80,000 unpublished pages (Garvey and Stangroom, 2009). He was the founder of pragmatism - inspired by reflections on Kant's "Critique of Pure Reason" - a term he first employed in his article "How to Make Ideas Clear" in 1878 (Muraro, 2008).

As described by Peirce (1998) the abductive logic is the most flawed, however the only one through which it is possible to create new hypotheses. The hypothesis is the only logical inference that can be understood as a conjecture, which must be subjected to experience and can only be accepted if a link with reality is possible. Inference is the controlled adoption of a belief, established as a consequence of another knowledge. Thus, abduction can be understood as the only kind of logical inference capable of formulating a new hypothesis.

In the deduction one knows "what" (object of analysis) and "how" (way of proceeding). Therefore, one can estimate the "results". In induction one knows "what" and by observing the "results" one obtains the "how" through creative exercises. If the aspired result is the creation of "value" for others, two distinct abduction logics can follow. The first logic - usually used in engineering - is the "what" proposition as a function of a previously known "how", estimating the creation of a certain "value". The challenge in the second abduction logic, considered "open", is the discovery of "what" without the previous definition of "how", seeking to achieve some "value" aspired as a function of two variables. The second abduction logic resembles the complex problems currently found in organizations, and their ideal resolution is realized through Design practices (Dorst, 2011).

\section{Double diamond}

The discovery phase is characterized as a divergent thinking stage, in which project participants keep an "open mind" enabling, and influencing, the maximum generation of insights (Design Council, 2011). Through the analysis of market data, interviews, observation, among others, the team begins to elaborate questions and hypotheses (Design Council, 2015).

The definition phase is characterized as a stage of convergent thinking, in which the filtering, disposal and selection of ideas are performed. The knowledge gained in the "discovery" phase is analysed, problems are structured as well as the best proposals, which are prepared for prototyping (Design Council, 2011). Common questions from this step: What matters most? What should we test first? What will be economically viable? The goal is to develop creative frames that synthesize the challenge of the project (Design Council, 2015).

The development phase is characterized as a divergent thinking stage, in which the main concepts previously defined are tested, evaluated and refined with customers (Design Council, 2011). The trial and error process helps designers improve and refine their ideas (Design Council, 2015). 
The implementation phase is characterized as a convergent thinking stage, in which the product, service or strategy in question is finalized and launched in the "open" market (Design Council, 2011).

\section{Process management}

Hammer (1998) points out that the inherent characteristics of a process-driven company is the focus on customer satisfaction, since the overall goal of the company should be to deliver more value faster and at a lower cost. To develop a high performance process the company needs to provide an enabling environment for it. The organizational project or redesign should consider strategies, competencies, organizational structure, performance indicators, in line with the processes (Hammer, 2007).

Taking as its premise that law firms are made up of people who sell their attorneys' solutions, skills and experience, create documentation of legal precedents and seek continuous maintenance of the legislative and jurisprudential basis, it can be inferred that, although such institutions do not manage knowledge by themselves, they generate it through those who completely perform some functions. As stated by Nonaka and Takeuchi (1997), "the creation of organizational knowledge, therefore, must be understood as a process that broadens organizationally the knowledge created by individuals, crystallizing it as part of the organization's knowledge network." Thus, we see born organizational knowledge, which can be understood as an organizational process.

According to Selem and Bertozzi (2005), "the legal world is looking for a new way, an effective but ethical way of adapting to the terrible competition and future shortage of sufficient lawsuits to meet all lawyers." This appreciation is significant considering the competitiveness and market demands of today's society.

\section{CASE STUDIES: THE CASE OF THE FIRM BASTOSJURIS}

Bastosjuris law firm was founded ten years ago and currently stands out as one of the most important in the city of Três Rios. With a growing demand for customers from outside the state of Rio de Janeiro, it sought the company Respondit for the optimization of its organizational processes and alignment of the Strategic Planning.

The approach used to meet the demand of Bastos Juris was an interdisciplinary methodology designed from the perspective of Design Thinking double diamond, which appropriates concepts and tools of Lean Manufacturing and Process Engineering.

\section{Methodological Inferences}

From the methodological perspective, this qualitative-quantitative research was based on the triangulation of information and methods. In the four steps - Discovery; Define; Develop; Deliver - information from literature, interviews, co-creation and prototyping events, among others, was used as insights and guidelines.

The research question that guided the development of this article was "Will the communion between Design Thinking, Lean Thinking and Process Management generate good project results?". The objective of this research is configured as the demonstration of effectiveness of the application of multiple methodologies from the perspective of Design Thinking.

Below will be described the four steps of this research, its main results and impacts for the company.

\section{Discovery}

During Desk Research we searched for topics related to this project using the keywords: "processes", "design thinking", "lean thinking", "process management", "legal", "advocacy", among others. The structuring of this knowledge subsequently enabled a first "comparison" 
between the status quo and the state of the art, which enriched the diagnosis and the first "round" of suggestions for improvement.

Bastosjuris value stream was built through interviews. It was used as a basis for the development of the tool "Makigami-Respondit" - framework that contemplates the main steps of the value stream, the employees involved, control mechanisms, problems and opportunities. The aforementioned tools come from lean thinking and were crucial to the results of this project.

The result of Makigami workshop with internal employees was a detailed understanding of the organizational value stream, the processes and people responsible for them, the integration between employees, their current management and eventual problems and opportunities.

After these dynamics were prioritized the critical processes for organizational optimization were mapped through individual interviews. The ARPO software was used to perform this activity.

\section{Define}

The analysis of the primary processes linked to the value stream allowed the reduction of NVAAs, the establishment of control mechanisms proposals seeking "zero error", the better integration between the sectors, and the use of other opportunities.

Below (Figure 1) is an image of the "Makigami-Respondit" tool considering the new value stream, the divisions of responsibilities, and opportunities and issues that should be considered for their full implementation.

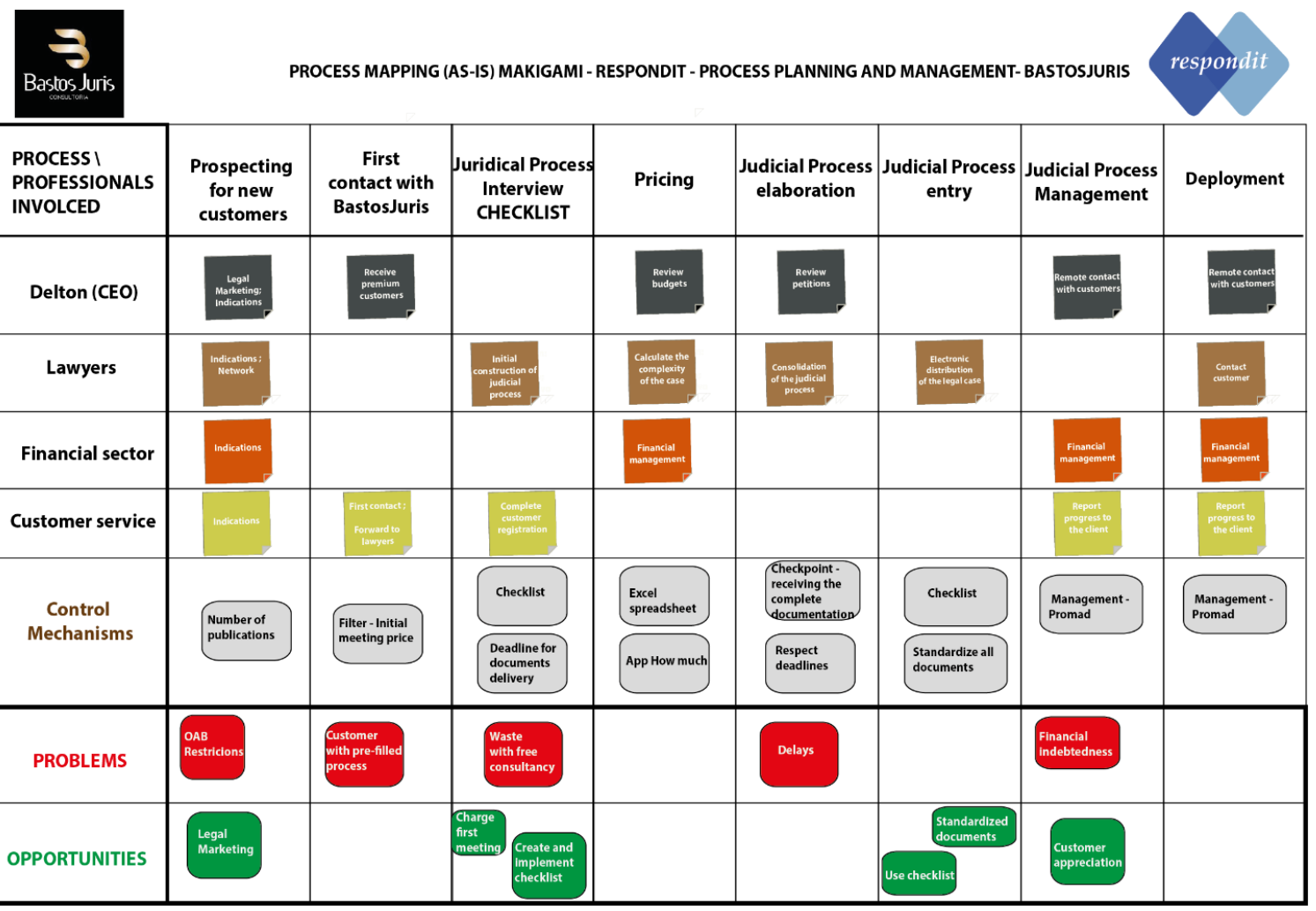

Figure 1. Makigami-Respondit "TO-BE"

In this stage a comparison was made between the status quo and the "state of the art", enriching the suggestions for improvements that were developed later.

The "AS-IS" processes were printed to be validated, adjusted and refined with the various collaborators. This activity was carried out in a workshop format, seeking to absorb the maximum tacit knowledge of the team. 


\section{Develop}

This stage was marked by co-creation and prototyping in loco. The control mechanisms were prototyped from a "blank sheet" considering three criteria, which are: what the main "functions" of the checklist are; what information it should contain; and which the best graphic distribution is. The prototypes sought to synthesize all these criteria in one page, facilitating their interpretation and implementation. Below (Figure 2) is an image of some prototypes created in the field:

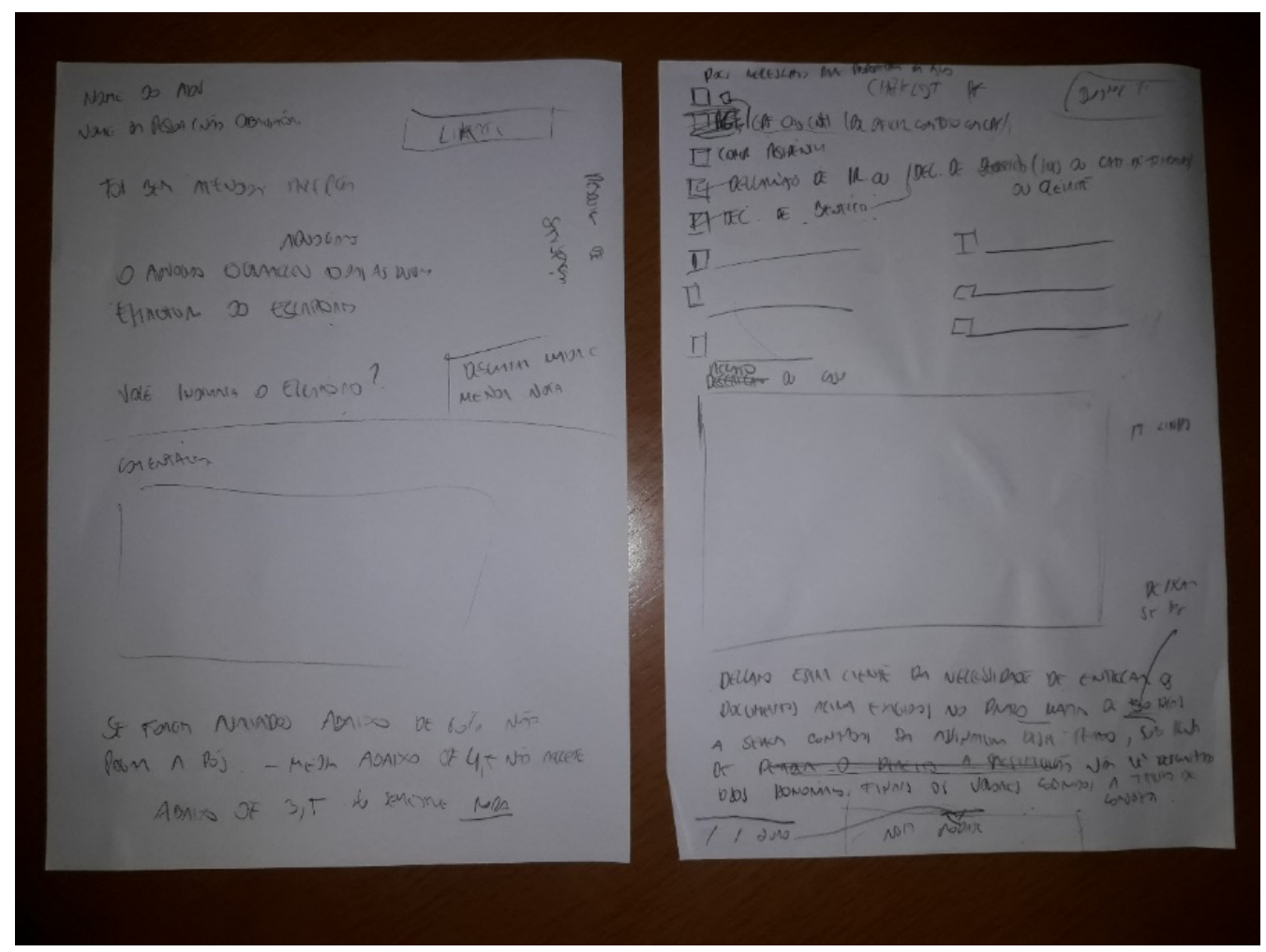

Figure 2. Prototyping - Checklists

At this stage the processes already reviewed were also printed to be validated again with the collaborators.

Seeking the strategic alignment to the new scenario of the company, and the operationalization of the proposed innovations, the strategic roadmap and business model of BastosJuris were co-created. They were implemented in conjunction with the new processes in the later step.

\section{Implementation}

At this stage all the innovations developed were implemented at BastosJuris. Several innovation, management and strategy techniques were implemented. The images below illustrate an example of some of them (Figures 3, 4, 5, 6, 7): 


\section{$\triangle \mathrm{BASTCS}$}

CHECKLIST

Documents required to enter the Legal Process:

D Current Social Contract

$\square$ All changes already made to the Social Contract

$\square$ National proof of legal entitycard

$\square$ Official document with photo of the Legal Representative

$\square$ Specific documentation from the comercial board

$\square$

$\square$

Client Case Report:

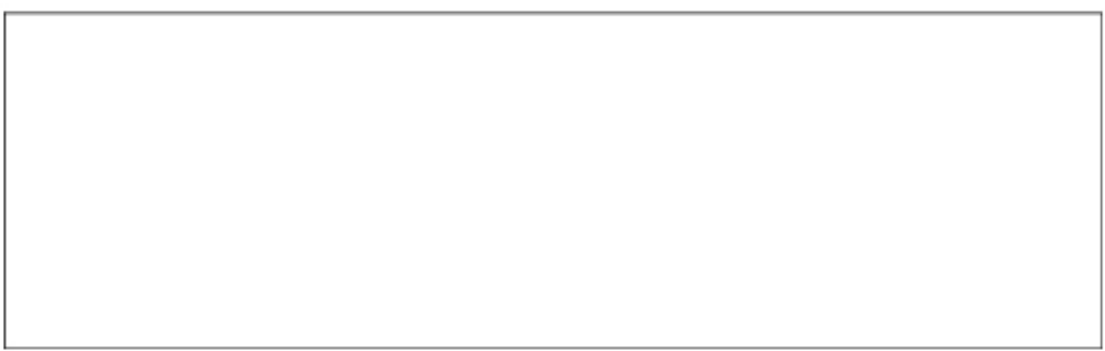

I declare to be aware of the need to deliver the documents required above within a maximum period of days, to be counted from the signing of this term, under penalty of not being deducted from the final fees the amounts charged for consultation. I also declare the veracity of the facts reported above.

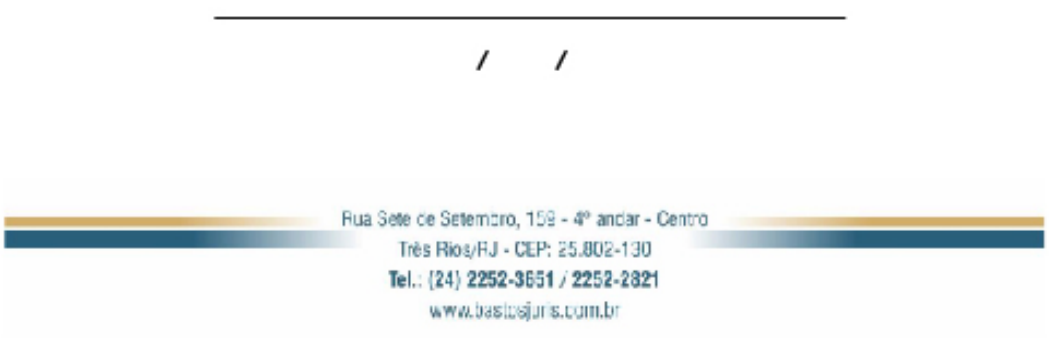

Figure 3. Example of the checklist already implemented

Process mapping was performed using the ARPO Professional software. The modeling standard was EPC (Event-driven Process Chain). Below the flowchart of the lawyers attendance process: 


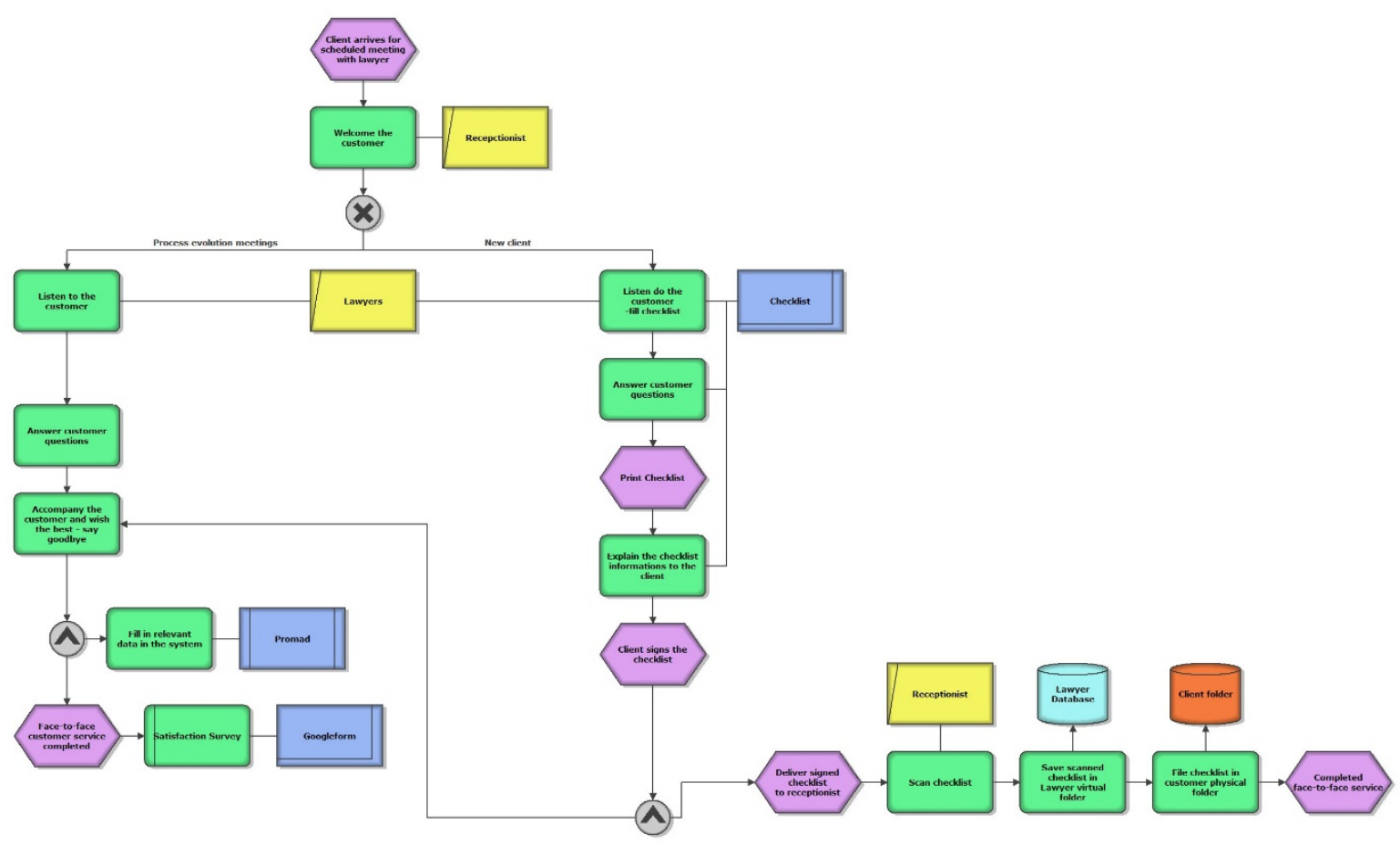

Figure 4. Face-to-face attendance flowchart

One of the control mechanisms proposed for BastosJuris was the application of a satisfaction survey. It uses the likert scale and open questions to measure customer satisfaction. The survey was created in googleforms and is automatically applied via email after each step of the customer experience.

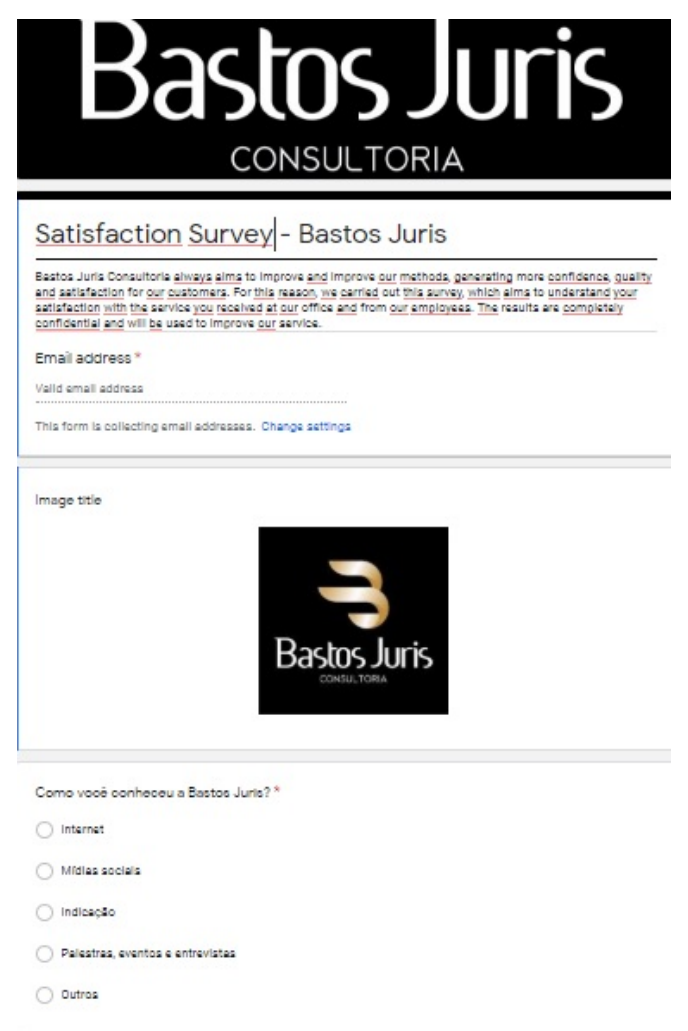

Figure 5. Satisfaction Survey - google forms 
Business models translate how businesses deliver value to their clients (Nakano, 2019). The new business model was implemented already considering the innovations resulting from the project with Respondit. Below is the canvas of BastosJuris:

Business Model Canvas - BastosJuris

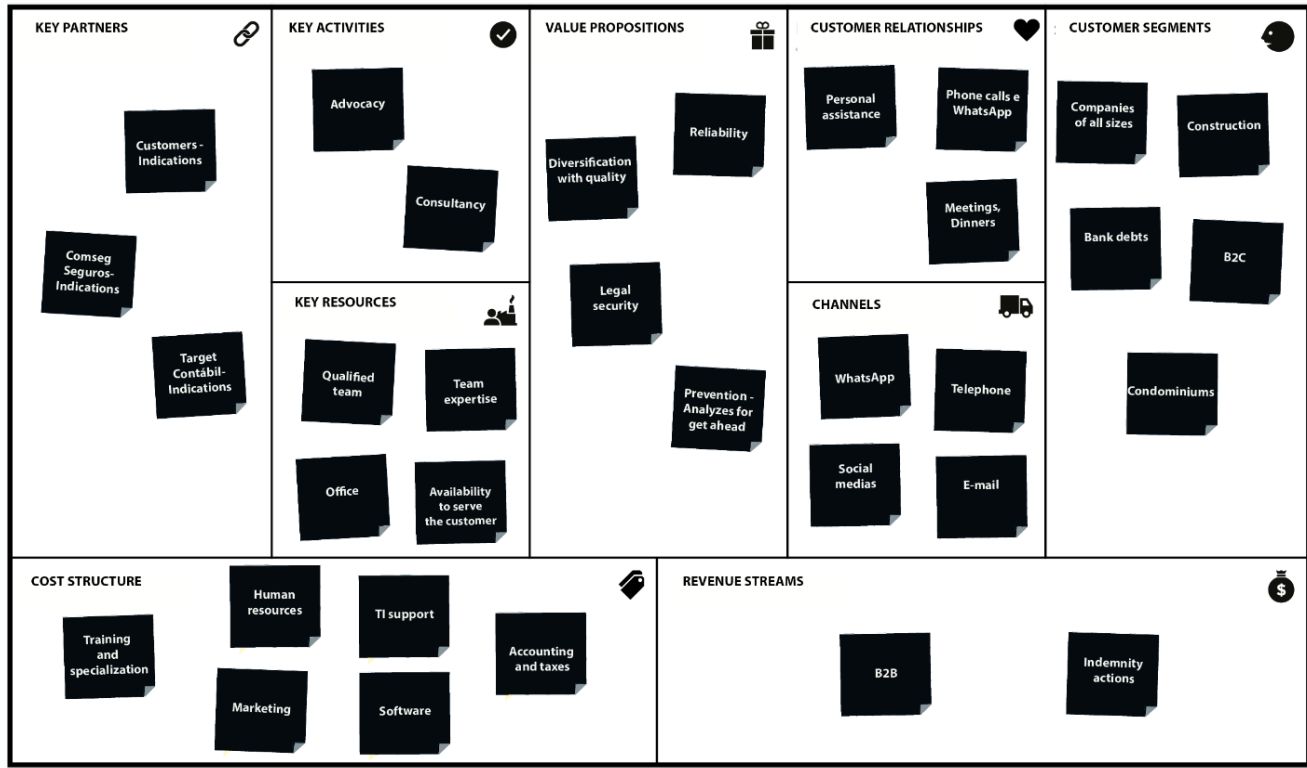

Figure 6. Bastosjuris business model canvas

Roadmaps are visual summaries of complex scenarios, and call for intensive processes of innovation and creativity, as well as considerable capacity for visual expression, both for the related ideation and in running the roadmapping sessions. Below is the Strategic Roadmapping of BastosJuris:

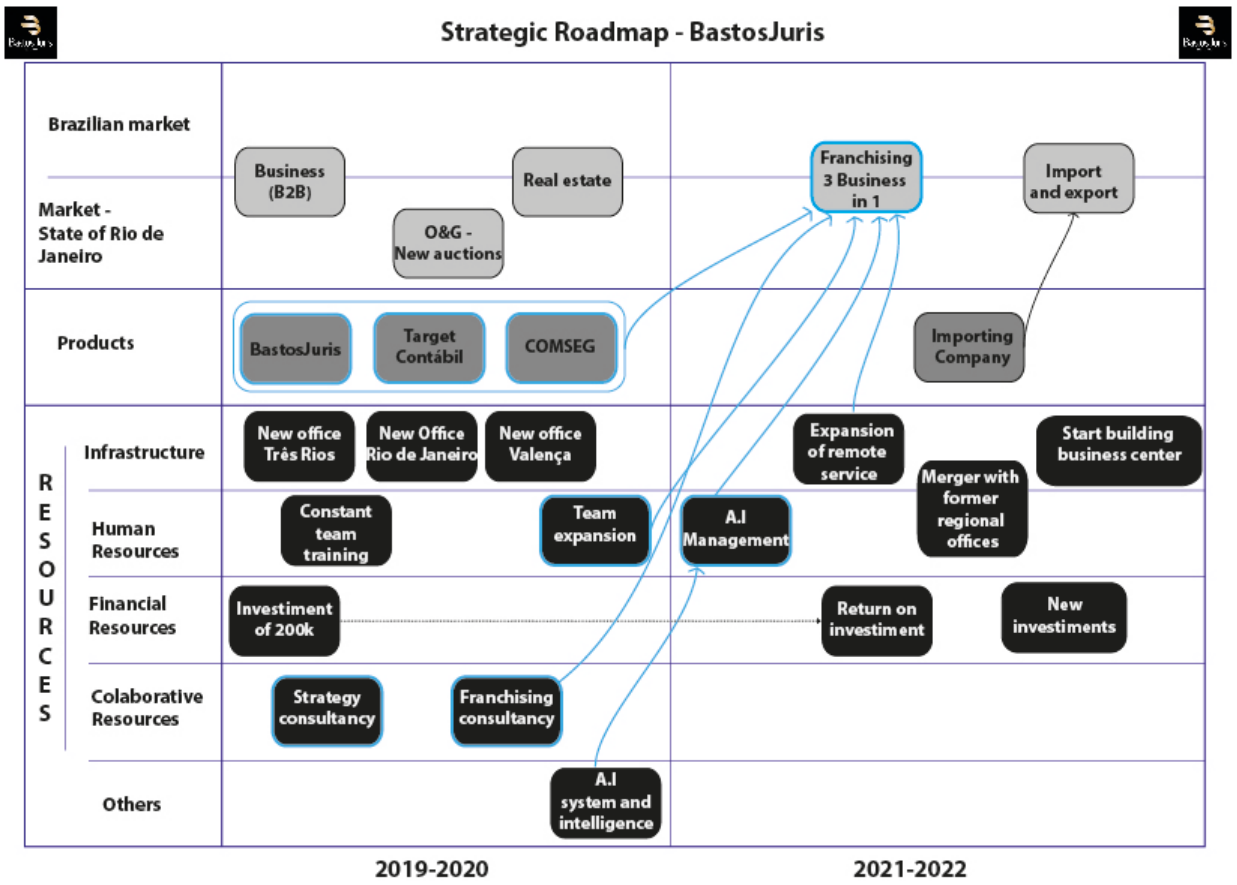

Figure 7. BastosJuris Strategic Roadmap 
The table 1 illustrates a portion of the organizational changes implemented through this project:

Table 1. Organizational changes and developments

\begin{tabular}{|c|c|c|c|c|}
\hline Value stream & $\begin{array}{l}\text { Management } \\
\text { Innovations }\end{array}$ & Implementation & Explanation & $\begin{array}{l}\text { Measurement } \\
\text { Frequency }\end{array}$ \\
\hline $\begin{array}{c}\text { Prospecting } \\
\text { New } \\
\text { Customers }\end{array}$ & $\begin{array}{l}\text { Legal Marketing - } \\
\text { Lawyer } \\
\text { publications. } \\
\text { KPI: Office } \\
\text { Annual } \\
\text { Publication }\end{array}$ & $\begin{array}{l}\text { Satisfaction Survey } \\
\text { Application }\end{array}$ & $\begin{array}{l}\text { By fostering } \\
\text { structured } \\
\text { publications, } \\
\text { BastosJuris will } \\
\text { expose itself to } \\
\text { renowned media } \\
\text { and attract } \\
\text { potential higher } \\
\text { value-added } \\
\text { customers. } \\
\text { Through customer } \\
\text { evaluation the } \\
\text { service will be } \\
\text { constantly } \\
\text { improving, always } \\
\text { aiming to improve } \\
\text { the experience of } \\
\text { its customers, and } \\
\text { consequently their } \\
\text { loyalty. }\end{array}$ & $\begin{array}{c}\text { Daily - Complete } \\
\text { Customer } \\
\text { Satisfaction } \\
\text { Worksheet }\end{array}$ \\
\hline
\end{tabular}

\section{ANALYSIS AND DISCUSSION OF RESULTS}

The double diamond was the guiding structure of the design logic of the design solution presented in this article. The methodology made it possible the framing of distinct - but complementary - philosophies and tools of related areas of Science have been crucial to obtain an innovative result.

The initial project briefing - process analysis and improvement - was the heart of this methodology. Through the Makigami-Respondit tool the value stream was understood and the essential processes for its optimization were later mapped. New processes have already been implemented with KPIs and associated checklists.

The "lean" philosophy has as its main pillar the reduction of activities that do not add value based, among other aspects, on the elimination of errors and waste. In this project we eliminated the rework generated by the conference of all petitions, decentralizing this activity to their respective managers - expert lawyers. With this the entrepreneur is allocating his time in activities that add value to his business.

The implementation of checklists aimed at ensuring "zero error" in some aspects, as well as serving as an interface and information for internal and external collaborators.

All the above innovations were co-created with the collaborators involved and prototyped on site. Through this process of abductive inferences, the experiments were refined and aligned with the actual demands of the users, thus, reducing eventual failures and further adjustments.

Structured follow-up through KPIs induces the continuous improvement process, ensuring that BastosJuris continues to improve the excellence service it provides to its customers.

The project ROI during execution was $815 \%$. However, most innovations could not yet be measured as a comparative analysis will be performed with the previous year's historical series at the end of 2019. 


\section{CONCLUSION}

Design is an essentially interdisciplinary activity. For the field to be able to meet the increasingly complex demands imposed by the market it is necessary its "association" with related areas of Science - with Engineering and Social Sciences.

The application of Design in strategic contexts is limited by the aggregate knowledge of the individuals involved in the project or research. As it is an "open" methodology, it is understood that interdisciplinary contributions are necessary for the realization of excellence projects.

In the case of Bastosjuris described here, the results were only possible because the methodology used was composed by Design Thinking, Process Engineering and Lean. The engagement with employees through prototyping and co-creation, focusing on productivity improvement and error elimination, seeking process optimization and implementation of a management model through continuous improvement, illustrates only one of the possible trajectories arising from mixed methodologies. In this case, "orchestrated" by the double diamond.

This case seeks to stimulate the synergy of Design Thinking with other methodologies, since in its logical roots the abduction seeks to solve problems through the formulation and experimentation of artifacts, and they must be generated with an "open mind" without the old shackles of the past or erroneous predictions of the future.

With regard to the academic contributions, the present study carried out the empirically and holistically variables linked to sustainable management practices, innovation, strategy and their consequent elements, in convergence with the research agenda of the management field, which focuses on results for individuals (employees) and organizations.

The research fulfilled its objective of demonstrating that Design Thinking can guide projects that use multiple methodologies to construct effective responses. The project described had an ROI of $815 \%$ during its execution and fostered several new initiatives for those involved.

Regarding its relationship with articles written in the field of Design, the research shows practical results of the effectiveness of the methodology used in the interdisciplinary context. As future perspectives, it is hoped that this article will stimulate new research that associates Design Thinking with other methodologies, reinforcing intrinsic interdisciplinarity as the essence of the field.

The main contribution of this article is also its limitation. As there is no similar research in the literature to compare with, it is not possible to induce success based in other initiatives. However, we seek to promote and encourage the development of similar new researches that take interdisciplinarity as a guide for organizational success.

\section{REFERENCES}

Caulliraux, A. (2014). "Design Thinking: Criando com (e para) seus clientes", in X Congresso Nacional de Excelência em Gestão, Rio de Janeiro.

Caulliraux, A., Proença, P., and Cardoso, V. (2013), “Synergies between Strategic Design and Roadmapping: a development roadmap for the Rio de Janeiro State Biotechnology Cluster", in CADMC 2013: University of Cambridge, Cambridge Academic Design Management Conference, Cambridge.

Cautela, C. and Zurlo, F. (2006), Relazioni produttive - design e strategia nell'impresa contemporânea, Ed. Aracne, Roma.

Design Council (2015), Design methods for developing services. London: Design Council.

Design Council (2015), The Design Process: What is the Double Diamond? London: Design Council.

Dickson, B., Friedman, E., and Ross, L. (2011) Innovating in health care - An environment adverse to change. Touchpoint: The Journal of Service Design, Vol. 3, No. 2, pp. 48-53.

Franzato, C. (2010), "O design estratégico no dialogo entre cultura de projeto e cultura de empresa", Strategic Design Research Journal, Vol. 3, No. 3, pp. 89-96.

Garvey, J. and Stangroom, J. (2009), Os Grandes Filósofos. São Paulo: Editora Madras. 
Hammer, M. (1998), "A empresa voltada para processos", Management, No. 9, pp. 6-9.

Hammer, M. (2007), "A auditoria de processos", Harvard Business Review, Vol. 4, No. 2, 73-84.

Liao, I.H. (2005), Designing a lean manufacturing system: A case study, Masters dissertation, School of Engineering and Applied Science, Binghamton University State University of New York, New York.

Liker, J. (2005), O modelo Toyota: 14 Princípios de gestão do maior fabricante do mundo. New York: Mc GrawHill companies, Inc.

Martin, R. (2009), The Design of Business. Why design thinking is the next competitive advantage. Boston: Harvard Business School Press Book.

Monden, Y. (1998), Toyota production system: An integrated approach to just-in-time, 3rd ed. Norcross, Georgia: Engineering and Management Press.

Mootee, I. (2013), Design Thinking for strategic innovation. New Jersey: John Wiley \& Sons.

Muraro, D. (2008), A importância do conceito do pensamento deweyano: relação entre pragmatismo e educação, Tese de Doutorado em Educação, Coordenação dos Programas de de Pós-graduação da Faculdade de São Paulo, Universidade de São Paulo, São Paulo, 228 p.

Nakano, D.A.V.I. (2019), "Digital music, online outlets and their business models. Rio de Janeiro", Brazilian Journal of Operations \& Production Management, Vol. 16, No. 4, pp. 581-91. http://dx.doi.org/10.14488/BJOPM.2019.v16.n4.a4.

Nonaka, I. and Takeuchi, H. (1997), Criação do Conhecimento na Empresa: como as empresas geram a dinâmica da inovação. Rio de Janeiro: Campus.

Peirce, C. (1998), The essential Peirce. Bloomingtion: Indiana University.

Selem, L. and Bertozzi, R. (2005). A reinvenção da advocacia. Rio de janeiro: Ed. Gryphus.

Authors contribution: Adriano Caulliraux - Data collection and data analysis; Delton Bastos - Data collection and data analysis; Robson Amarante de Araujo - Writing; Stella Regina - Writing 